\title{
Effect of cimetidine treatment in the prevention of gastric ulcer relapse: a one year double blind multicentre study
}

\author{
E HENTSCHEL, K SCHÜTZE, W WEISS, E RÜDIGER, G JUDMAIR, \\ W REICHEL, E KERSTAN, AND J HORTON
}

\begin{abstract}
From the First Department of Medicine, Hanuschkrankenhaus, Vienna, Austria; First Department of Medicine, Krankenanstalt Rudolfstiftung, Vienna, Austria; Department of Medicine, University Clinic of Innsbruck, Innsbruck, Austria; Fourth Department of Medicine, Wilhelminenspital, Vienna Austria; and Smith Kline and French Research, Welwyn, Herts.
\end{abstract}

SUMMARY One hundred and forty six gastric ulcer patients were given open treatment using $1 \mathrm{~g}$ cimetidine daily to heal their ulcers. Of 130 who completed the acute treatment period of eight weeks, $112(86 \%)$ had healed ulcers. Of these 112 patients with healed ulcers, 108 entered a one year double blind study to compare the effect of cimetidine maintenance therapy ( $400 \mathrm{mg}$ at night) with placebo. Of the 84 patients available for assessment at the end of one year, $86 \%$ in the cimetidine treated group were in remission compared with $45 \%$ in the placebo treated group $\left(\chi^{2}=15.03 ; p<0.001\right)$. There were similar losses from non-compliance and drop out in both groups. The incidence of untoward effects and significant drug related laboratory abnormalities was low. The results indicate that cimetidine heals nearly $90 \%$ of acute gastric ulcers within eight weeks and that subsequent low dose maintenance treatment at night offers a considerable benefit over placebo therapy.

Although the efficacy of cimetidine in the healing and prevention of recurrence of duodenal ulceration has been well documented, ${ }^{1-7}$ the evidence for similar efficacy in the treatment of gastric ulcer is less clear. There is now good evidence to suggest that gastric ulcers can be healed using cimetidine $1 \mathrm{~g}$ daily for four to eight weeks. ${ }^{8-10}$ The documentation covering maintenance treatment is rather sparse, however, and based on a variety of doses in relatively small patient populations. ${ }^{11-15}$ In two studies cimetidine was compared with carbenoxolone and deglycerinised liquorice respectively. ${ }^{15} 16$ The results appear to show similar recurrence rates, but the studies were limited to six months only.

This multicentre study was designed to investigate in a one year double blind placebo controlled study the effect of prophylactic therapy with cimetidine on gastric ulcer recurrence.

Address for correspondence: Dr E Hentschel, Hanuschkrankenhaus der Wiener Gebietskrankenkasse, Heinrich Collin-Strasse 30, A-1140 Wien, Austria.

Received for publication 26 November 1982

\section{Methods}

PATIENTS

Patients who had healed gastric ulcers after treatment for four to eight weeks treatment with cimetidine $1 \mathrm{~g}$ daily were included in the study. Malignancy was excluded by biopsy before the initial healing treatment and only patients without concurrent duodenal ulceration and with an intact stomach were included. Patients were randomly allocated to treatment with either cimetidine $400 \mathrm{mg}$ (two tablets) at night, or matching placebo. Patients were seen every two months for up to one year unless there was clinical deterioration which required an earlier visit. At each visit symptoms, untoward events and changes in medication were recorded. At the six and 12 month visit or whenever symptoms suggested a recurrence, endoscopy was performed. Blood samples were obtained before entry, and at all of the bimonthly visits. The following parameters were investigated: red and white cell count, haemoglobin, haematocrit, platelets, and reticulocyte counts, bilirubin, SGOT, SGPT, alkaline phosphatase, LDH, BUN, 
creatinine, uric acid, and serum electrolytes. At each endoscopy where an ulcer was demonstrated, material for histological and cytological examination was obtained.

\section{STATISTICAL METHODS}

Results were analysed by Wilcoxon's rank sum test for comparison of age, duration of ulcer disease, and ulcer size. All other comparisons of frequencies and results were done by chi square test or Fisher's exact test in case of small numbers.

\section{Results}

Of the 146 patients who began treatment, 112 patients had a healed ulcer after four or eight weeks treatment with open cimetidine. Three of these patients refused to continue into the double blind prophylactic phase and one patient was referred for surgery because of primary hyperparathyroidism. The remaining 108 patients were randomly allocated either to cimetidine prophylaxis ( $400 \mathrm{mg}$ at night) or to placebo treatment. During the one year's treatment 12 patients $(22.2 \%)$ in each group were lost to follow up, the reasons for drop out being listed in Table 1. Four patients died during the one year follow up, (cimetidine treatment: one congestive cardiac failure; one myocardial infarction; one bleeding from oesophageal varices. Placebo treatment: one congestive cardiac failure), the cause of death being considered unrelated to either ulcer disease or the drug therapy. One placebo treated patient underwent a portocaval shunt operation. Eight cimetidine and seven placebo patients failed to attend the clinic, and all contact was lost despite follow up letters, so that the reason for noncompliance is unknown.

Of the 108 patients who were available for analysis during the maintenance phase there was no significant difference with respect to age, sex, duration of ulcer disease, or time to healing of ulcer between the two treatment groups (Table 2). Patients allocated to placebo, however, had significantly more ulcers located in the antrum than those on cimetidine $\left(\chi^{2}=8.04 ; p<0.05\right)$. This

Table 1 Reasons for withdrawal from trial during maintenance therapy

\begin{tabular}{lcc}
\hline Reasons & Cimetidine & Placebo \\
\hline Death & 3 & 1 \\
Surgery & 0 & 1 \\
Side effect & 1 & 3 \\
Failure to attend clinic & 8 & 7 \\
Total & 12 & 12 \\
\hline
\end{tabular}

Table 2 Demographic data for patients followed up during maintenance trial

\begin{tabular}{llll}
\hline & $\begin{array}{l}\text { Cimetidine } \\
\text { Group }\end{array}$ & $\begin{array}{l}\text { Placebo } \\
\text { Group }\end{array}$ & Significance \\
\hline $\begin{array}{l}\text { Men:women } \\
\begin{array}{l}\text { Mean age } \\
\text { in years (range) }\end{array}\end{array}$ & $20: 22$ & $20: 22$ & NS \\
$\begin{array}{l}\text { Mean duration of } \\
\text { ulcer disease }\end{array}$ & $63.5(28-80)$ & $58(26-82)$ & NS \\
$\begin{array}{l}\text { in years (range) } \\
\text { Time to heal ulcer }\end{array}$ & $3 \cdot 0(<1-30)$ & $2 \cdot 5(<1-45)$ & NS \\
$\begin{array}{l}\text { 4 weeks } \\
\text { 8 weeks }\end{array}$ & 25 & 27 & \\
$\begin{array}{c}\text { Site of ulcer } \\
\text { Corpus }\end{array}$ & 15 & 17 & \\
Angulus & 27 & 20 & $\left(\chi^{2}=8.04\right)$ \\
Antrum & 15 & 10 & $\mathrm{p}<0.05$ \\
\hline
\end{tabular}

NS $=$ Not significant $(p>0 \cdot 05)$. As some patients had two or three ulcers the total number of ulcers is higher than the total number of patients.

difference was already present at the beginning of the maintenance phase and not altered by subsequent drop outs $\left(\chi^{2}=9 \cdot 16 ; p<0 \cdot 05\right)$. Forty two patients in each treatment group completed the one year maintenance study or suffered an endoscopically proven relapse.

Six $(14 \%)$ of the cimetidine treated patients relapsed, $36(86 \%)$ remained healed whereas with placebo treatment $23(55 \%)$ relapsed and $19(45 \%)$ patients remained healed, this difference being highly significant $\left(\chi^{2}=15 \cdot 03 ; p<0 \cdot 001\right)$. No evidence of malignancy was shown in any of the ulcers that recurred during maintenance treatment.

Seven (24\%) of 29 recurrences were asymptomatic, the proportion of asymptomatic recurrences being similar in both groups: two of six during cimetidine treatment and five of 23 during placebo treatment (Table 3).

Table 3 Recurrence of ulceration during maintenance treatment and relationship to presence or absence of symptoms

\begin{tabular}{lllll}
\hline & \multicolumn{2}{l}{ Patients (no.) } & & \\
\cline { 2 - 5 } & \begin{tabular}{l} 
Completed \\
one year \\
\cline { 3 - 5 } Treatment
\end{tabular} & $\begin{array}{l}\text { Study } \\
\text { stumptomatic } \\
\text { relapse }\end{array}$ & $\begin{array}{l}\text { Asymptomatic } \\
\text { relapse }\end{array}$ & $\begin{array}{l}\text { Total } \\
\text { relapses }\end{array}$ \\
\hline Cimetidine & 42 & 4 & 2 & $6(14 \%)$ \\
Placebo & 42 & 18 & 5 & $23(55 \%)$ \\
\hline
\end{tabular}

A more detailed picture of the pattern of relapses and drop out is shown in the Figure. In both groups the majority of relapses occurred in the first six 


\begin{tabular}{|l|c|c|c|c|c|c|c|}
\hline CIMETIDINE & $54 / 0$ & $50 / 1$ & $48 / 1$ & $47 / 5$ & $46 / 5$ & $45 / 5$ & $42 / 6$ \\
\hline PLACEBO & $54 / 0$ & $49 / 2$ & $45 / 5$ & $43 / 17$ & $42 / 19$ & $42 / 19$ & $42 / 23$ \\
\hline
\end{tabular}

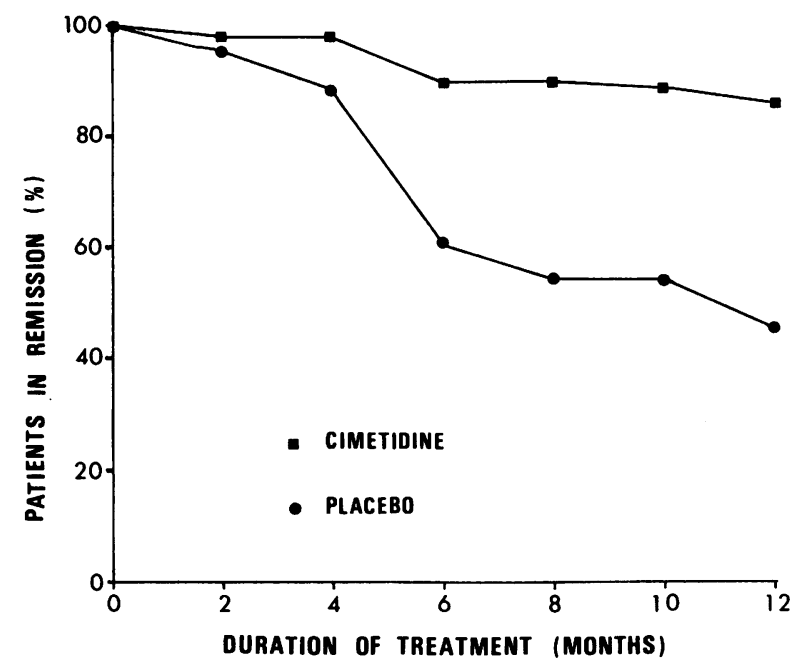

Figure Corrected cumulative remission rate showing patients in remission as percentage of total number of patients presenting at each bimonthly control and number of patients who had endoscopically been shown to have reulceration in the preceding months. Figures above graph separated by an oblique bar represent absolute number of patients presenting and total number of recurrences at each control.

months: five of six during cimetidine treatment, 17 of 23 during placebo treatment. It should be emphasised that the curves do not show the exact time of onset of the asymptomatic recurrences, as routine endoscopy was only performed at six and 12 months.

With the exception of one patient who originally had an antral ulcer and developed a duodenal ulcer, all recurrences of gastric ulceration occurred at or very close to the site of the presenting lesion. Ulcers recurred in the corpus in $7.4 \%$ of cimetidine patients and $40 \%$ of placebo patients, in the antrum in $39 \%$ of placebo patients and in none of the cimetidine patients. The recurrence rate in the angulus was $26 \%$ in the cimetidine patients, however, and $80 \%$ in placebo patients, a finding which indicated a trend, but did not reach statistical significance $\left(x^{2}=5 \cdot 21 ; p<0 \cdot 1\right)$.

\section{UNTOWARD EVENTS AND LABORATORY TEST}

\section{ABNORMALITIES}

During prophylactic treatment four patients were withdrawn because of suspected side effects. Three patients receiving placebo developed chest pain, herpes zoster, or thrombocytopenia respectively. One patient receiving cimetidine requested withdrawal of the treatment because of fatigue. The following untoward events were observed without interrupting the study: three patients receiving placebo reported impotence, vertigo, and pruritus respectively, and four patients presented with gynaecomastia (due to hepatic cirrhosis), transient rash, anaemia or thrombocytopenia. Four patients receiving cimetidine reported headache, disturbed sleep, loss of libido (a female patient) or pruritus, and two patients developed transient anaemia or leucocytosis. One patient developed gynaecomastia during the eighth month of treatment, some weeks after starting therapy with spironolactone for incipient heart failure, the gynaecomastia clearing by the 12th month after withdrawal of spironolactone.

Four patients taking cimetidine and nine taking placebo had abnormal liver function tests (increased bilirubin, alkaline phosphatase and/or SGOT) on more than one occasion. In all cases this could be attributed to pre-existing alcoholic liver damage. No other significant abnormalities of laboratory data were seen.

\section{Discussion}

In a large and unselected population of patients with endoscopically proven gastric ulcer, an $86 \%$ healing 
rate was achieved using cimetidine $1 \mathrm{~g}$ daily for four to eight weeks. This result compares favourably with others $^{8-10}$ who have reported healing rates of 60 to $80 \%$ during acute therapy under controlled conditions. Trials where cimetidine was not significantly superior to placebo in healing gastric ulcers were characterised by comparatively small numbers of patients or high placebo healing rates. ${ }^{18-20}$

The recurrence rate for gastric ulcers after healing is reported to be at least $60 \%$ without treatment. ${ }^{19}$ The need for effective drug prophylaxis, at least for selected patients, seems obvious. Only a few studies so far have dealt with maintenance treatment of gastric ulcer ${ }^{11-14}$ reporting significantly fewer recurrences with cimetidine treatment than with placebo. This study strongly confirms these results.

In this study, after randomisation to either cimetidine or placebo maintenance treatment, the distribution of ulcer localisation turned out to be unequal. Significantly fewer ulcers of the antrum were treated with cimetidine than with with placebo. The authors do not believe that this imbalance had a major influence on the final outcome of the study. It seems very unlikely that a small difference in the number of antral ulcers between the cimetidine and placebo treatment groups would have a noteworthy effect on relapse rates. This appears to be emphasised by the fact that no antral ulcers relapsed on cimetidine.

Twenty four per cent of the relapses in this trial were asymptomatic, about $80 \%$ occurring in the first six months. As this applies to both treatment groups, relapses on cimetidine do not appear to differ from those on placebo except that they occur significantly less frequently. It appears from this study that a significant improvement in remission can be expected for maintenance treatment of healed gastric ulcers with cimetidine. As decisive prognostic factors for gastric ulcer patients are not known, it is still a matter of debate who should receive long term prophylactic treatment. We would suggest that those taking ulcerogenic drugs and those at major risk from ulcer complications would benefit most from long term maintenance therapy.

\section{References}

1 Korman MG, Hetzel DJ, Hansky J, Shearman DJC, Don G. Relapse rate of duodenal ulcer after cessation of long-term cimetidine treatment: a double-blind controlled study. Dig Dis Sci 1980; 25: 88-91.

2 Massarrat S, Hausmann L, Heuser E, Klingemann HG, Schubotz R. Long term treatment of duodenal ulcer. Z Gastroenterol 1979; 17: 6-33.

3 Gudmand-Hoyer E, Jensen KB, Krag E, Raskmadsen J, Rahbek I. Prophylactic effect of cimetidine in duodenal ulcer disease. Br Med J 1978; 1: 1095-7.
4 Bardhan KD, et al. Comparison of two doses of cimetidine and placebo in the treatment of duodenal ulcer: a multicentre trial. Gut 1979; 20: 68-74.

5 Berstad A, Aadland E, Carlsen E, Myren J, Semb LS, Kruse-Jensen A. Maintenance treatment of duodenal ulcer patients with a single bedtime dose of cimetidine. Scand J Gastroentol 1979; 14: 827-83.

6 Dronfield MW, Batchelor AJ, Larkworthy W, Langman MJS. Controlled trial of maintenance cimetidine treatment in healed duodenal ulcer: short and long-term effects. Gut 1979; 20: 526-31.

7 Burland WL, Hawkins BW, Beresford J. Cimetidine treatment for the prevention of recurrence of duodenal ulcer: an international collaborative study. Postgrad Med J 1980; 56: 173-6.

8 Frost F, Rahbek I, Rune SJ, et al. Cimetidine in patients with gastric ulcer: a multicentre controlled trial. Br Med J 1977; 11: 795-9.

9 Lambert R, Bader JP, Bernier J, et al. Treatment of gastric and duodenal ulcer with cimetidine; a multicenter trial. Gastroenterol Clin Biol 1977; 1: 855-60.

10 Navert $\mathrm{H}$, Larose $\mathrm{L}$, Beaudry $\mathrm{R}$, et al. Cimetidine is effective in the treatment of gastric ulcer. Gastroenterology 1978; 74: 1072.

11 La Brooy SJ, Taylor RH, Ayrton C, et al. Cimetidine in the maintenance treatment of gastric ulceration. (Abstract) Hepatogastroenterology (Suppl). Hamburg: XI International Congress of Gastroenterology, 1980.

12 Machell RJ, Ciclitira PJ, Farthing MJG, Dick AP, Hunter JO. Maintenance cimetidine in prevention of peptic ulcer disease. Lancet 1978; 1: 633.

13 Jensen KB, Mollmann KM, Rahbek I, Madsen JR, Rune SJ, Wulff HR. Prophylactic effect of cimetidine in gastric ulcer patients. Scand J Gastroenterol 1979; 14: 175.

14 Bodemar G, Walan A. Two year follow up after one year's treatment with cimetidine or placebo. Lancet 1980; 1: 38-9.

15 Bianchi Porro G, Petrillo M. A controlled trial of cimetidine and carbenoxolone sodium in gastric ulcer: short- and long-term study. Drugs Exptl Clin Res 1979; 5: $173-6$.

16 McAdam WAF, Pacsoo C, Morgan AG. A comparison between Caved-S and cimetidine in gastric ulcer treatment and subsequent maintenance therapy. (Abstract) Hepatogastroenterology (Suppl). Hamburg: XI International Congress of Gastroenterology, 1980.

17 Piper DW, Shinners J, Greig M, Thomas J, Waller SL. Effect of ulcer healing on the prognosis of chronic gastric ulcer. Gut 1978; 19: 419.

18 Ciclitira PJ, Machell RJ, Farthing MJ, Dick AP, Hunter JO. Experience with cimetidine in the treatment of gastric ulceration. Gut 1977; 18: 419-20.

19 Dyck WP, Belsito A, Fleshler B, Lieberrmann TR, Dickinson PB, Wood JM. Cimetidine and placebo in the treatment of benign gastric ulcer: a multicenter double-blind study. Gastroenterology 1978; 74: 410-5.

20 Englert $\mathrm{E} \mathrm{Jr}$, Freston JW, Graham DY, et al. Cimetidine, antacid and hospitalization in the treatment of benign gastric ulcer. Gastroenterology 1978; 74: 416-25. 